\title{
Students' Perception of Digital Literacy Competence as Learning Sources
}

\section{Iful Rahmawati Mega}

STKIP Muhammadiyah Bangka Belitung, Indonesia

Email: Iful.rahmawati@stkipmbb.ac.id

\begin{tabular}{|c|c|}
\hline ARTICLE INFO & ABSTRACT \\
\hline Article History: & This study was carried out to define the students' perception of digital \\
\hline Received 18 Februari 2020 & literacy competencies as learning sources held by the students of English \\
\hline Accepted 28 Februari 2020 & $\begin{array}{l}\text { Education Study Program of STKIP Muhammadiyah Bangka Belitung as } \\
\text { active users of internet pointed on the internet searching, hypertext } \\
\text { navigation, content evaluation, and knowledge assembly by theory of Paul } \\
\text { Gilster (1997). This research uses a descriptive qualitative method. Subjects } \\
\text { in this research were } 9 \text { students determined using a purposive sampling }\end{array}$ \\
\hline Keywords: & technique, with the subject criteria is the students who are actively using \\
\hline $\begin{array}{l}\text { Students' perception, } \\
\text { Digital literacy, Learning } \\
\text { sources }\end{array}$ & $\begin{array}{l}\text { the internet more than } 4 \text { hours a day to browse the internet as educational } \\
\text { sources. The results of this research indicate that all of the respondents are } \\
\text { not literate yet because they do not have all the indicators in digital } \\
\text { literacy. But, only one of nine students answered all the indicators on digital } \\
\text { literacy, the respondent has stated as well competencies in internet } \\
\text { searching, hypertext navigation, content evaluation, and knowledge } \\
\text { assembly. So, from the indicators of digital literacy competencies, it can be } \\
\text { implied that only one of nine students who have a good perception of } \\
\text { digital literacy as learning sources. }\end{array}$ \\
\hline
\end{tabular}

\section{INTRODUCTION}

In era 4.0, digital literacy has come up with a huge impact. Digital literacy is the ability to understand and use information from a variety of online sources. Digital literacy skills are used to deal with the internet's explosion of knowledge. The reality nowadays, internet users are growing up, many parties can easily access and deliver information freely to their users. The internet used by users has been varied and used not only to build a relationship, reach communication through social networking sites but also to browse information for literate knowledge. In the meantime, learning sources comes in a variety of platforms with their respective characters. Also, internet media platform is transformed as learning sources, especially in searching scientific issues as references. Even the digital era is blowing up, the use of the internet today has not been accompanied by the awareness of each user to think 
critically. Indonesia is stated as one of the biggest internet users in the world. Based on Asosiasi Penyelenggara Jasa Internet Indonesia (APJII) in 2017, Indonesian internet users are 143,26 million or $54,68 \%$. And this percentage will increase over time in line with digital development. Because the digital era is huge up, it needs critical thinking and creativity to access and share the information. In this era, every person has to understand digital literacy as an important thing. Digital literacy must be understood as important as the ability to read, write, and calculate. As living in the digital era (one-touch and one-click), people have the chance to access the information fast, get interaction with others, but not all the contents of information deliver the positive content. Digital character is valuefree so that every person has the chance as a role in it. Because of the wide impact of digital sources, the public or the citizen must be a good user and good netizen. Digital literacy is the ability to understand and use information from a variety of online sources. Digital literacy skills are used to deal with the internet's explosion of knowledge. As stated by Davis \& Shaw (2011) in Chabibie (2017) that digital literacy is the relationship ability through hypertextual information, in the meaning of reading on a non-sequential computerbased system or digital platform. Therefore, analyzing skills is an important factor. Gilster (2007) in Chabibie (2017), digital literacy means that the ability in reading, understand, and analyzing the variety of digital sources. It is important that people have the ability to reading and analyzing online information in order to get valid information or news. The ability to find new information that is accounted for will be more important around this quickening digital technology. So that the reading ability of Indonesian people, especially the young generation need to be directed into understanding intelligence in reading comprehension to understand the digital information. For that, digital literacy must be supported as a learning mechanism that is structured in the curriculum.

Digital literacy is acquainted by Paul Gilster (1997), Gilster stated that every people has to fit the ability out to understand and use the information from various digital sources. And also he adds that digital literacy is the ability to using digital equipment in daily life. Hague (2010) said that digital literacy is the ability to create and share in different modes and form; to create, collaborate, and communicate effectively, as well ass to understand how and when using digital technology properly. While UNESCO sees digital literacy as modern life skills that need to be mastered. In line with Martin (2006) digital literacy is awareness, attitude, and the ability of individual in using the digital tools and facilities to identify, access, manage, integrate, evaluate, analyze, and synthesize the digital resource, build the new information, create the media expression, and communicate with others, in the context of certain life situations, to allow the social act constructively.

Digital literacy covers people understanding of digital content. People must be aware of every content on the internet is not equal in sharing information, they are not similar in quality of information. According to Basuki (2013) 
when someone accessing and browsing the internet more often, they will have the ability to differentiate whether the information has good or bad quality. From these statements, digital literacy covers the technical ability in using tools and ICT, as well as covers the people's knowledge and skills in understanding the contents, so the goal is able to design the new knowledge. Therefore, it can be stated that digital literacy is someone's competencies in operating digital media in finding, using, managing, creating, evaluating, and transferring the information properly, wisely, and responsibly.

According to Gilster (1997), someone is called literate in digital if they have the ability in four aspects of digital components; first, internet searching is the ability to use the internet and do various activities in it. This competency covers two components they are, the ability to find the information on the internet using the search engine, and the ability to do various activities. Second, hypertext navigation is the ability to read and understand the navigation of hypertext in the web browser. This competency covers four components, they are knowledgeable about hypertext and hyperlink along with how it works, knowledge about the differences between reading textbooks and browsing sources through the internet, knowledge about the web works, and ability to understand the web page characteristics. Third, content evaluation is the ability to think critically and give the assessment to what is found in online sources, as well as the ability to identify the validity and completeness information that is referred by a hypertext link. This competency covers five components, there are the ability to differentiate between information layout and content that is the users perception in understanding the web page layout visited, the ability to analyze the background of information that is people awareness to search for further information and the creator, the ability to evaluate web address through understanding the various domain for each country or institution, the ability to analyze the web page, and the knowledge about $F A Q$ in newsgroup or group discussion. Fourth, knowledge assembly is the ability to arrange the knowledge, build a set of information from various sources along with the ability to collect and evaluate the fact or opinion properly without prejudice. This competency covers four components, they are the ability to search information through internet, the ability to design the personal newsfeed or news update notification or discuss several topics by joining or subscribing the newsgroup, or mailing list, the ability to do crosscheck or recheck about the information that is found, the ability to use all kinds of media to prove the truth information, and the ability to arrange information sources that is found in internet to the real life that is not connected in network.

Based on this theory, the researcher sets the theory based on Paul Gilster, there are four aspects that must be followed; they are internet searching, hypertext navigation, content evaluation, and knowledge assembly. These digital literacy competencies are conducted as the unit analysis in the aspect of students' perception of digital literacy. From this 
description, the purpose of this study is to define the students' perception of digital literacy competencies as learning sources held by the students of English Education Study Program of STKIP Muhammadiyah Bangka Belitung as active users of the internet.

\section{RESEARCH METHODOLOGY}

This study was qualitative research conducted for English Education Study Program of STKIP Muhammadiyah Bangka Belitung students. Qualitative research is a kind of research that the findings are not related to statistic procedural or other calculation and as a purpose to reveal something holistic-contextual through collecting data from a natural background with the researcher as the subject instrument (Sugiarto, 2015).

This research was used a descriptive study method, this method is to describe or analyze a matter of research but not as stated to design a wide conclusion (Sugiyono, 2012). The subjects of this research were 9 students of English Education Study Program of STKIP Muhammadiyah Bangka Belitung, Moleong (2010) describes research subjects as information, means that people in the background of the research is used to give information about the situation and condition of research background. This research used purposive technique sampling, in Crossman (2019) a purposive sample is a non-probability sample that is selected based on characteristics of a population and the objective of the study.

These nine subjects were characterized based on certain criteria, they were internet active users, operating the internet more than 4 hours a day. As stated by Andrew, a researcher at Oxford University, in Sativa (2017) from the calculation of the research, the ideal time for students doing online browsing is 257 minutes or 4 hours 17 minutes in a day. With this duration, Andrew adds that students not only have technology operating ability but also they can do socialization to others. While the object of this research is digital literacy competencies in learning sources. To collect the data in this research, the researcher used to interview and documentation method. The interview method used an in-depth interview with the unstructured interview. According to Sugiyono (2012), the unstructured interview is a free interview where the researchers do not use the systematical questions. The questions are only for guiding the researcher to do the depth interview. The researcher did the interview to get the depth information and built the situation informally, like did the daily conversation. So, the informant felt comfortable doing the interview.

Furthermore, documentation was also used in collecting the data. The researcher used the recorder to record the data interview. In analyzing the data, the researcher used qualitative data analysis, there were data reduction, display data, and drawing the conclusion. Data reduction was used to analyze the data when the researcher collects the data, it was for limiting the data that was not used. While display data was used to categorized the data, related to the group data. So the analyzed data become synchronized. And then drawing the 
conclusion, the conclusion was the final step of analyzing the data, but the researcher had confirmed it and revised it to the conclusion to find the final data. The trustworthiness in this study used triangulation sources. According to Patton in Moleong (2014) defines that triangulation sources are comparing and checking the degree of trust of information through different times and instruments in qualitative research. The triangulation sources of this study invited information and technology experts.

\section{FINDINGS AND DISCUSSIONS}

This research discussion describes the students' perception of digital literacy competence as learning sources. The competencies were analyzed from four aspects, they are internet searching, hypertextual navigation, content evaluation, and knowledge assembly. The data that was described is analyzed based on the Gilster theory.

In the first discussion, digital literacy competence reviewed from the internet searching aspect. In this aspect, the students were assessed to some indicators; they were the activities of the students when browsing the website, the kind of website most visited, the information found when browsing the website, the knowledge of the web search components, the students' ability on how to search the information. The students' perception of digital literacy reviewed from the internet search engine was in middle categorized. From nine students, there were one student who could not understand all of the aspects of the internet searching aspect. The rest students were having a good perception of the internet searching aspect. Although all students are active internet users, they still got difficulties in understanding the website's appearance. Because the appearances are too much. And when browsing information, they only focus on the information they need. According to Gilster (1997), internet searching is someone able to use the internet and do many activities there. There are some activities that we can do, there are using and managing the email account periodically, joining a newsgroup or mailing list, doing online business, doing an online transaction, doing work, searching the learning sources, reading online news, listening music, watching movies or videos. From this description, students still get difficulties in doing many online activities.

In the second discussion, the digital literacy competence reviewed from hypertext navigation. Stated in Gilster (1997) hypertext navigation is the ability to read and understand dynamically about hypertext navigation. Moreover, Gilster described that understanding hypertext navigation is not only relates to its hypertext but also the knowledge of information available on the internet is different from the information in the textbook. Hypertext navigation competence assessed some indicators, there was students' knowledge about hypertext and hyperlink, students' knowledge about hypertext characteristics, students' understanding about website layout, students' understanding about web page characteristics, students' information on the internet and in the textbook. Students' perception of digital literacy as 
learning sources was in low perception. From nine students, there were six students who could not explain the indicators well, so only three students who understood about the indicators or the aspects of hypertext navigation. From the description, it can be concluded that the perception of students' of digital literacy in the aspect of hypertext navigation is low perception.

The third discussion, the digital literacy competence reviewed from the content evaluation. Gilster (1997) explained that content evaluation is someone able to think critically and give an assessment to the online information as well as identify the validity and the completeness information that suggested from the hypertext link. Content evaluation competencies have assessed some indicators, there is the ability to differentiate the layout and the content of information, the ability to analyze the correctness of the information, the ability to analyze the web page. Students' perception of digital literacy as learning sources was in middle perception. From nine students, there were two students who could not explain the aspects well. So the seven students the rest were having good perception in content evaluation. They had an awareness to evaluate the online information well. All the students are active internet users, they also did an evaluation on the content evaluation, they did not only access one website to search information, but they browsed others to link to make sure that the information is valid and correct. They also asked other people, friends or family about the correctness of the information.
The fourth discussion, the digital literacy competence reviewed from knowledge assembly. Gilster (1997) stated that arranging the knowledge assembly is the ability to arrange the knowledge, build information from other sources, and evaluate the facts and opinions properly without prejudice. Gilster added the competencies needed not only critical thinking but also the ability to learn about arrange the knowledge, build the information from different sources. And in the end, the users have to create the final conclusion to design new knowledge. Knowledge assembly competencies have assessed some indicators, there is the ability to finish the task through browse the information in the search engine. The ability to finish the task by joining the discussion group, the ability to analyze the background of the information, the ability to use other sources in finding the information, the ability to communicate and discuss to other people in order to solve the problem. Students' perception of digital literacy as learning sources was in middle perception. From nine students, there were two students who could not explain the indicators well. So the seven students were having good perception in knowledge assembly. The seven students used the internet as a learning source and opened other links to synchronize each information. When they found the new information, they also asked other people to confirm or discuss it. It did work that the internet helped them much as learning sources. From all the discussion, it can be concluded that all students have not literate yet of digital as learning sources, the indicators of digital literacy competencies have not been answered 
properly, only one of nine students who have a good perception of digital literacy as learning sources.

\section{CONCLUSIONS AND SUGGESTIONS}

From the discussion result, it can be concluded that students have not literate well, and have a middle perception toward digital literacy competencies. The results of this research indicate that all of the respondents are not literate yet because they do not have all the indicators in digital literacy. But, only one of nine students answered all the indicators on digital literacy, the respondent has stated as well competencies in internet searching, hypertext navigation, content evaluation, and knowledge assembly. So, from the indicators of digital literacy competencies, it can be implied that only one of nine students who have a good perception of digital literacy as learning sources. Most students feel difficult and hesitant about browsing the website. Most of them open websites only focus on what they need, not to try to share or open other sources that do not relate to the topics. They afraid about did wrong sharing.

This research only to investigate the perception of the students on digital literacy as learning sources, so it has not been found about the influence of their critical thinking. Based on this, it is suggested to the next researcher to find other problems related to digital literacy and students' understanding of online information.

\section{BIBLIOGRAPHY}

1) APJII. 2017. Penetrasi dan Perilaku Pengguna Internet Indonesia. Retrieved from: https://www.apjii.or.id

2) Basuki, S. 2013. Literasi Informasi dan literasi Digital, Blog Library And Information Science.

3) Chabibie, Hasan. 2017. Literasi Digital Sebagai Tulang Punggung Pendidikan. Retrieved: http://pustekkom.kemdikbud.go.id/lite rasi-digital-sebagai-tulang-punggungpendidikan/

4) Crossman, Ashley. 2019. Purposive Sampling. Received from: www.thoughtco.com/purposivesampling-3026727

5) Gilster, Paul. 1997. Digital Literacy. New York: John Wiley \& Sons, Inc.

6) Hague, Cassie and Sarah Payton. 2010. Digital Literacy Across the Curriculum: a Futurelab Handbook. United Kingdom. Sources: www.nfer.ac.uk/publications/FUTLO 6/FUTL06.pdf

7) Martin, A. 2006. Literacies for Age Digital Age. Madigan (eds), Digital Literacies for Learning. London: Facet

8) Moleong, Lexy J. 2010. Metodologi Penelitian Kualitatif. Bandung: Remaja Rosdakarya.

9) Moleong, Lexy, J. 2014. Metode Penelitian Kualitatif. Edisi Revisi. PT Remaja Rosdakarya, Bandung

10) Nuryani, Ely. 2017. Literasi Digital, Alternatif Pembelajaran Masa Depan. Retrieved from: http://radarsemarang.com/2017/12 /08/literasi-digital-alternatifpembelajaran-masa-depan/

11) Sativa, Rahma Lillahi. 2017. Berapa Lama Waktu Ideal Gunakan Gadget. 
Retrieved

from:

https://inet.detik.com/cyberlife/d-

3398914/berapa-lama-waktu-ideal-

gunakan-gadget

12) Sugiarto, Eko. 2015. Menyusun Proposal Penelitian Kualitatif: Skripsi dan Tesis. Yogyakarta: Suaka Media.

13) Sugiyono. 2012. Metode Penelitian Kuantitatif, Kualitatif, dan $R$ \& D. Bandung: ALFABETA 